Article

\title{
Sustainable Economy and Development of the Rural Territory: Proposal of Wine Tourism Itineraries in La Axarquía of Malaga (Spain)
}

\author{
Gorka Zamarreño-Aramendia ${ }^{1, *(D)}$, Elena Cruz-Ruiz ${ }^{2}$ iD and Elena Ruiz-Romero de la Cruz ${ }^{1}$ (D) \\ 1 Department of Economic Theory and Economic History, University Málaga, 29013 Málaga, Spain; \\ emruiz@uma.es \\ 2 Department of Economics and Business Administration, University Málaga, 29013 Málaga, Spain; \\ ecruz@uma.es \\ * Correspondence: gzama@uma.es; Tel.: +34-951952226
}

check for updates

Citation: Zamarreño-Aramendia, Gorka, Elena Cruz-Ruiz, and Elena Ruiz-Romero de la Cruz. 2021.

Sustainable Economy and Development of the Rural Territory Proposal of Wine Tourism Itineraries in La Axarquía of Malaga (Spain). Economies 9: 29. https://doi.org/ 10.3390/economies 9010029

Academic Editor: Michał Roman

Received: 7 February 2021

Accepted: 25 February 2021

Published: 4 March 2021

Publisher's Note: MDPI stays neutral with regard to jurisdictional claims in published maps and institutional affiliations.

Copyright: (c) 2021 by the authors. Licensee MDPI, Basel, Switzerland. This article is an open access article distributed under the terms and conditions of the Creative Commons Attribution (CC BY) license (https:// creativecommons.org/licenses/by/ $4.0 /)$

\begin{abstract}
The certification of Malaga and Ronda wine route, within the model of certified wine routes in Spain, has given a new boost to wine tourism in Malaga. The study focuses on La Axarquía, located on the Eastern Costa del Sol in Southern Spain, which has been a reference point in the wine business since ancient times and has its own identity. This research aims at elaborating a diagnosis of the territory related to the possibilities offered by the area, from the perspective of the heritage resources and services provided by the winemakers outlining two efficient enotourism itineraries that enhance the value of the territory's resources. The methodology used starts with the study of the territory in order to profile the existing resources, a task that was complemented by the analysis of the documentary sources required in order to understand the peculiarities of the territory. From there, a process of interviews was carried out between April and November 2019 with $100 \%$ of the winemakers and around $70 \%$ of the territory's agents. The results of the research are specified in a SWOT (Strengths, Weaknesses, Opportunities, and Threats) analysis, which has allowed evaluating the possibilities of the enotourist development in La Axarquía, which is complemented with a proposal of two possible itineraries that will promote such development of the rural territory. The conclusions convey the possibilities of the territory of a tourist segment which puts its resources to good use and moves forward the deseasonalization and destructuring of tourism in Malaga, especially on the Eastern Costa del Sol, according to criteria of efficiency and profitability with wine as a reference, although it could be applied to other gastronomic and cultural resources linked to the tourist sector in other geographical areas.
\end{abstract}

Keywords: economy; sustainable development; wine routes; Axarquía; rural tourism

\section{Introduction}

Wine tourism has a special impact on rural economies (López-Guzmán et al. 2009) as it involves activities in wineries, events, as well as different hospitality activities (Carlsen and Charters 2006). Wine has gone from being a consumer product to favoring the establishment of a development model for the rural territory, which requires policies and actions that seek a change in the productive structure, with the objective of environmental sustainability, as well as the enhancement of the heritage and culture of villages and nations (Bruwer and Rueger-Muck 2019; Lourenço-Gomes et al. 2015).

The economic data on wine show the interest of this resource. In terms of production, in 2019 it reached 26,000 million liters, of which 24,400 were consumed. Italy (47.5 mhl), France $(42.1 \mathrm{mhl})$ and Spain $(33.5 \mathrm{mhl})$ represent $48 \%$ of the total production (OIV 2020). And if we consider the value of wine tourism, Italy was estimated at 2.5 billion euros with 14 million tourists (MTV 2020); France accumulated more than 10 million wine tourists who accounted for 5.2 billion euros for the sector (Saybus 2020). 
In Spain, the institution that channels this tourism in a regulated manner is ACEVIN (Spanish Association of Wine Cities). It is a body that has numerous objectives, among which stand out the promotion and collaboration with other European cities that traditionally produce wine and a proposal for responsible wine tourism that could be achieved through sustainability and competitiveness plans to apply the concept of Social Responsibility to the territorial, socioeconomic and cultural sphere of the Wine Routes (ACEVIN 2020).

In 2021 it integrates 30 routes, with more than 2000 associated companies that make up the wine tourism offer of the destinations that are members of the Wine Routes of Spain Club. A significant figure is the number of visits to wineries and museums of the Wine Routes in 2019, which amounted to 3,076,334, experiencing a growth over the previous year of $3.9 \%$ with an expenditure of just over 85 million euros per year, representing a growth of around $5.68 \%$. Turnover reached 256 million euros, adding the part corresponding to the catering, hotel, business and leisure sectors (ACEVIN 2020).

These data are a true reflection of the interest of a sector that, linked to tourism, exerts a great power of attraction in certain destinations, as they have placed value on tourism formulas that have rural areas as protagonists (Khartishvili et al. 2019). It should be noted that wine routes in destinations with tourist saturation can diversify the offer by revitalizing the inland (Díaz Armas 2008), as well as promote job creation and rural development by favoring the deseasonalization of demand, as stated by numerous authors (Álpizar and Maldonado 2009; Álvarez García et al. 2014; López-Guzmán et al. 2009; Ramis Hernández 2010).

Enotourism is defined as the movement of certain travelers for a holiday focused on getting to know certain areas and landscapes where wine is produced and carrying out activities that increase knowledge about this product (Elias Pastor 2006). It is a consolidated activity that is increasingly popular in countries with a long tradition in the Old World such as Spain, Italy, France, Portugal, Greece, Romania, Germany or Serbia (Coros et al. 2019; Dougherty 2012; Festa et al. 2020; Khartishvili et al. 2019; Koch et al. 2013; Lourenço-Gomes et al. 2015; Trišić et al. 2020; Vieira-Rodríguez et al. 2013; Wolikow 2014), implementing tourism strategies significantly in other places such as Australia, New Zealand, South Africa, Canada or the USA (Bruwer 2003; Hall et al. 2019a; Kirkman et al. 2013).

Wine routes are an opportunity for the promotion of cultural values, gastronomy and local products, with a special consideration for wine (Bessière et al. 2013; Etcheverria 2015). Thus, the aim of this work is to investigate the possibilities of La Axarquía to develop a wine route through itineraries that discover the tourist potential of the area. From an academic point of view, it is essential to analyze these routes with criteria of efficiency and profitability, since for the wine route to be an attractive destination, it is necessary to know the resources available in the territory and this is a particularly important factor, as it may be what initially motivates the tourist to visit the area (Gatti and Incerti 1997).

This study is located in a line of research that revolves around wine tourism and Málaga wine route (Ruiz-Romero de la Cruz et al. 2017), circumscribed in La Axarquía of Malaga as it is a place where the climate, landscape and culture add an important value to the traditional activity of making wines protected under the Certificates of Origin "Malaga", "Sierras de Malaga" and "Pasas de Malaga" (DDOMSPM). The conclusion of this research phase culminated in a publication that modelled the fundamental elements (Figure 1) that should be present in a wine route in general and specifically in La Axarquía (Cruz-Ruiz et al. 2020). The structure of this research is based on the knowledge of the potential of La Axarquía in Malaga (Spain), located in the southern Mediterranean. After a review of the literature, the methodology of the study is presented, consisting of a field study, an analysis of documentary sources and in-depth interviews with winemakers and agents involved in the sector. The results obtained made it possible to carry out a specific diagnosis of the territory by means of a SWOT analysis. On this basis, several proposals for wine tourism itineraries have been drawn up, outlined with economic criteria of profitability for the 
geographical area analyzed and its surroundings. The study ends with a discussion section and the conclusions.

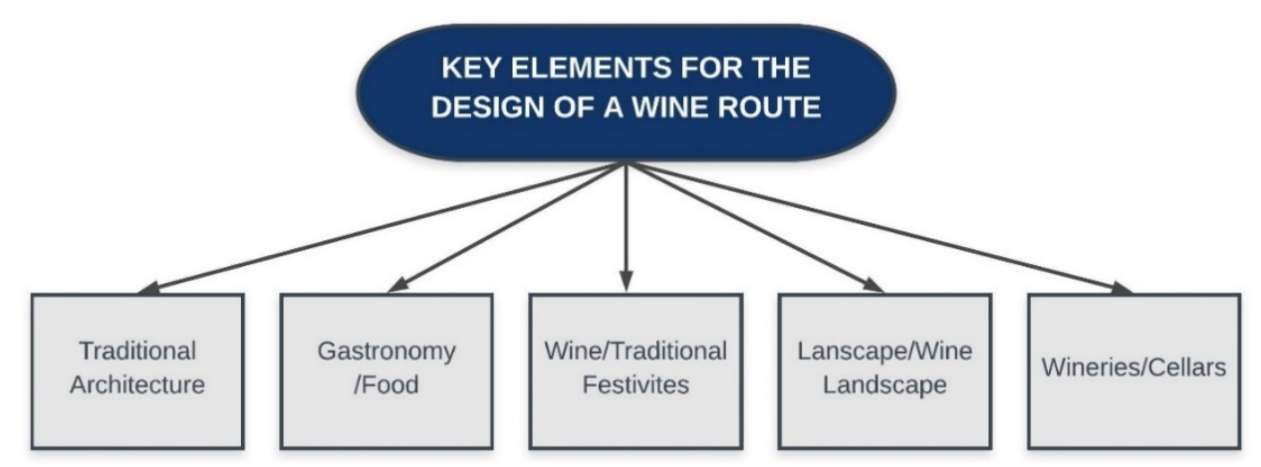

Figure 1. Key elements for the design of a wine route. Source: Cruz-Ruiz et al. (2020).

The research has raised the following questions:

$\mathrm{Q}_{1}$ : Does the territory of La Axarquía have sufficient resources to structure an enotourist offer that benefits its development?

$\mathrm{Q}_{2}$ : What is the diagnosis of the territory according to the stakeholders and winemakers?

$\mathrm{Q}_{3}$ : Do the existing wineries offer adequate services to contribute to the development of the rural territory?

$\mathrm{Q}_{4}$ : Is it possible to design wine tourism itineraries in La Axarquía with the elements available?

\section{Theoretical Background}

The development of wine tourism has grown and in many countries it has been due to wine routes, which can be defined as a set of duly marked itineraries that pass through a specific geographical area with a wine tradition, an essential issue if we take into account that they can be the reason for choosing a destination (Michael Hall 2013).

The study of the wine tourism phenomenon can be studied from three perspectives, Getz and Brown (2006) highlight its interest for regional development and its strategies. The opinions of consumers is another point of view that should be taken into account (Alant and Bruwer 2004; Garibaldi et al. 2017; Ruiz-Romero de la Cruz et al. 2017) and, on the other hand, the perspective provided by the wineries and the opportunity they have to promote and sell their product directly to visitors is of great analytical value (Carlsen 2011; Hall et al. 2019b; Peters 2018; Festa et al. 2020).

The enhancement of the territory's heritage is an important incentive for tourists to make the decision to visit a destination. This includes aspects such as the natural landscape and environment, heritage, cities, architecture, artefacts, vineyards, wineries and wines (Getz 2000; Getz and Brown 2006; Sparks 2007). The sensory enjoyment and pleasure produced by the consumption of wine, as well as by the territories where wine routes are located as the main motivation for wine tourists (Pulpón and Ruiz 2019; De Uña-Álvarez and Villarino-Pérez 2019; Wolikow 2014), make them a more demanding traveller in terms of quality, personalization and differentiation (Alonso and Liu 2012; Carlsen and Boksberger 2015; Fountain 2018; Vasco Santos et al. 2019).

Characterizing wine tourists allows us to build an appropriate offer, and numerous studies have produced profiles that bring us closer to their reality (Famularo et al. 2010; Garibaldi et al. 2017; Marzo-Navarro and Pedraja-Iglesias 2009; Quintal et al. 2017; Wade et al. 2006). Comparative studies between different types of tourists are not very abundant, although they are a very useful tool for making strategic decisions that make it possible to redirect the flow of visitors in order to deseasonalize tourism activity (Díaz Armas 2008; Ruiz-Romero de la Cruz et al. 2019).

The economic development potential of certain regions is linked to their ability to develop interesting tourism segments that offer economically viable alternatives and 
generate income for the local population (Roman et al. 2020). In this regard, wine tourism has an interesting attraction, generating visitor flows that bring significant economic benefit (Carlsen 2004; Gammack 2009; Hall and Mitchell 2000), providing greater brand awareness and involvement (Charters and Ali-Knight 2002), increasing the number of subsequent visits and encouraging purchasing behavior (Johnson and Bruwer 2007; Mitchell and Hall 2006; O'Neill et al. 2002). In this way, wineries are able to progressively add value to the destination, invigorating the traditional agricultural sector and innovating wine products with an impact on local economies. Hashimoto and Telfer (2013) highlight the contribution of wine routes to the improvement of wine product marketing strategies, economic performance and the efficiency of wine producers, while Carmichael and Sense analyze the competitiveness and sustainability of wine destinations (Carmichael and Senese 2012).

Wine routes are therefore an integrated strategy for a rural development (Ferreira and Hunter 2017; Northwood 2000; Williams and Kelly 2001). They are intimately linked to institutional decisions, as well as to the commitment and responsibilities acquired between the public and private spheres, a point at which noticeable divergences can arise (Ferreira and Hunter 2017; Northwood 2000; Williams and Kelly 2001). The design of an enotourism route must address different angles (Blum et al. 2014; Cruz-Ruiz et al. 2020; Getz et al. 2007; Getz and Brown 2006): gastronomic (Crespi-Vallbona and Mascarilla-Miró 2020; Millán Vázquez de la Torre and Pérez 2014), cultural (Arnáiz et al. 2019; Carrasco et al. 2019; Mitchell et al. 2012), natural heritage or terroir (Harvey et al. 2014; Holland et al. 2014) and formative (Buhalis and O'Connor 2005; Famularo et al. 2010; Wargenau and Che 2006).

Wine routes are defined by the vineyards, festivals, shows and especially the wineries of a given wine-producing region (Sigala 2014). All this in a geographical space where the exploitation of the vine and the wine-making takes place, where the wineries are located, where the interaction of the tourist with all the elements that make up the wine tourism route occurs (Cruz-Ruiz et al. 2020; Pulpón and Ruiz 2019), becoming, together with the terroir, basic elements in the conceptualization, design and management of wine routes (Brás et al. 2010; Pérez-Calderón et al. 2015) and being one of the primary resources in the wine business (Riera Palmero 2014; Yagüe Guillén and Jiménez 2002).

It is in this framework where wineries have a greater chance of creating an offer focused on the attraction of wine linked to the hedonistic experience (Bruwer and Alant 2009; Crespi-Vallbona and Mascarilla-Miró 2020). Collaboration between all the actors involved is decisive for generating value on the routes (López-Guzmán et al. 2009; Medina and Tresserras Juan 2008; Miranda Escolar and Fernández Morueco 2011; Vieira-Rodríguez et al. 2013; McGregor and Robinson 2019) and for the entire wine sector (Gomis et al. 2010). A collaboration that will be more productive if the possibilities of generating enotourism circuits in geographical areas that meet certain conditions are analyzed.

The study of the wine tourism offers and the needs of wine tourists has received contributions from the perspective of case studies (Chiodo et al. 2020; Holmes 2017; Ilieş et al. 2020; Trišić et al. 2020; Triantafyllou et al. 2020); which have led academics and specialists to understand the dynamics of this sector being assumed by the wineries as well as the public and private agents involved (Cruz-Ruiz et al. 2020).

All of these arguments highlight the importance of wine tourism and the interest in designing sufficiently attractive itineraries for the development of a sustainable tourism model. This is a challenge that institutions will have to take on from a multidisciplinary perspective, in which geographers, sociologists and economists, among others, will have to intervene (Fernández Portela and Vidal Domínguez 2020). In this way, the process of shaping a wine route as a tourism product is considered a way of conserving and enhancing the cultural heritage that belongs to the identity of the local population (Carrasco et al. 2019; Pulpón and Ruiz 2019), as well as an opportunity for economic diversification (Northwood 2000; da Silva et al. 2018; Wolikow 2014). 


\section{Territory of La Axarquía}

La Axarquía belongs to the easternmost part of the province of Malaga and has a total surface area of $1026.7 \mathrm{~km}^{2}$ (Figure 2). It is bordered by the Mediterranean Sea to the south, while to the north and east is the province of Granada and to the west it is bordered by the capital of Malaga and the regions of Antequera and Nororma (Lucena 2007). It has peculiar features, orography, farming systems and diversity of landscape and resources. The average altitude of the region is $391 \mathrm{~m}$, reaching a maximum altitude of $2069 \mathrm{~m}$, making it a territory with steep slopes alternating with open areas.

It has a Mediterranean-type climate, semi-tropical with mild winters and warm summers. In fact, Tejeda, Almijara and Alhama mountain ranges protect this territory from the cold north winds. Its subtropical latitude allows it to enjoy $3000 \mathrm{~h}$ of sunshine a year. Average temperatures in the coastal area range from an average of $10{ }^{\circ} \mathrm{C}$ in winter to $25^{\circ} \mathrm{C}$ in summer, being somewhat more extreme in the inland villages, especially in those located above the 900 meter mark (Carrión-García 2015).

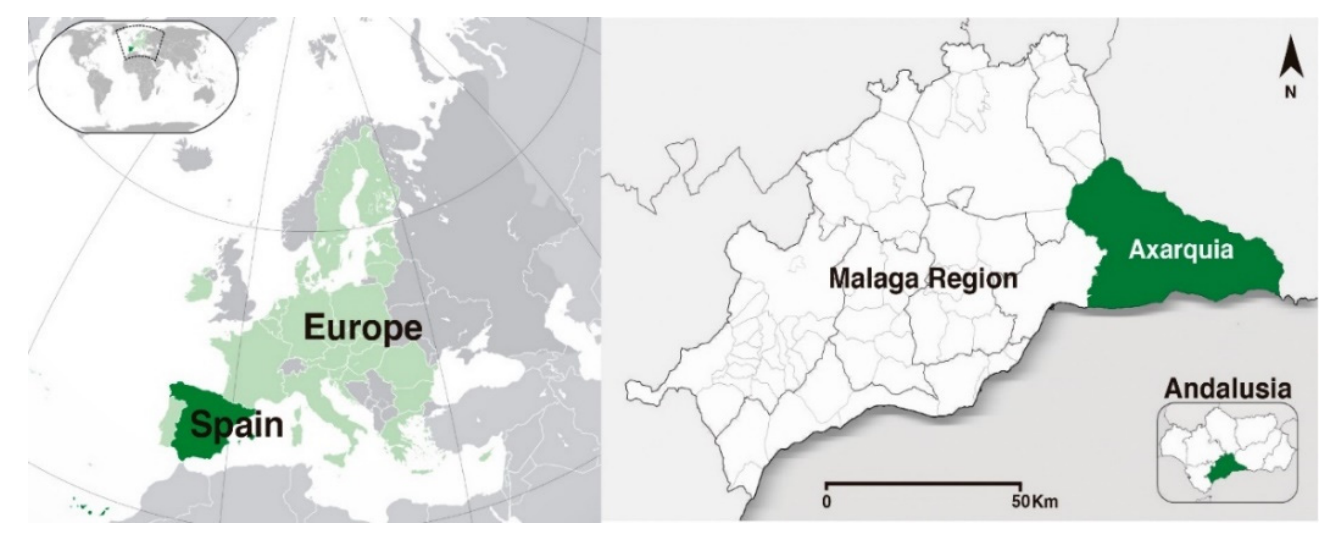

Figure 2. Location map of La Axarquía (Malaga, Spain). ETRS89 UTM 30S. Own elaboration.

The cultivation of vines in La Axarquía has certain peculiarities that make it attractive for wine tourism, including the grape harvest, which is one of the earliest in Europe that used traditional techniques for harvesting. The difficulty imposed by the physical environment on the tasks of maintaining the vines and harvesting the grapes, which have to be done by hand, means that this viticulture can be described as heroic (CERVIM 2020).

La Axarquía is currently made up of 31 municipalities and up to 67 districts. The total population in the last municipal census amounts to 214,323 inhabitants and, as shown in Table 1, Vélez-Málaga is the most populated urban center, with 81,643 inhabitants (IECA 2020), therefore it is part of the province of Malaga, but has a sufficient entity to be analyzed separately. It has its own bodies that identify it and work in a coordinated manner throughout the territory, such as the Association of Municipalities of La Axarquía (Mancomunidad de Municipios de la Axarquía) and the Centre for Rural Development of La Axarquía (Centro de Desarrollo Rural de la Axarquía, CEDER).

At present, the coast municipalities of La Axarquía have a much higher population density than those of the inland, which means a strong urban pressure on the coast strip (Almeida García and López Cano 2003). Table 1 shows the towns and their surface areas, with Vélez-Málaga, Rincón de la Victoria, Nerja, Torrox and Algarrobo standing out as the most densely populated. On the other hand, the least populated municipalities are those located inland, marked by a rugged terrain and more complicated accesses, which may influence their tourist potential, the latter being Salares, Árchez, Alfarnatejo, Macharaviaya, Sedella, Cútar, Totalán and Canillas de Albaida. 
Table 1. Population of La Axarquía.

\begin{tabular}{|c|c|c|}
\hline Municipality & Surface (has.) & Population \\
\hline Vélez Málaga & 157.9 & 81,643 \\
\hline Rincón de la Victoria & 27.51 & 47,179 \\
\hline Nerja & 85 & 21,091 \\
\hline Torrox & 51 & 17,234 \\
\hline Algarrobo & 9.73 & 6444 \\
\hline Cómpeta & 54 & 3922 \\
\hline Colmenar & 66 & 3376 \\
\hline Frigiliana & 41 & 3009 \\
\hline Periana & 58.76 & 3048 \\
\hline Benamocarra & 6 & 3011 \\
\hline Riogordo & 41 & 2724 \\
\hline Alcaucín & 45.1 & 2230 \\
\hline La Viñuela & 27.22 & 2034 \\
\hline Almáchar & 15 & 1811 \\
\hline Sayalonga & 18.3 & 1681 \\
\hline Canillas de Aceituno & 42 & 1677 \\
\hline Benamargosa & 12.12 & 1511 \\
\hline Comares & 25.5 & 1315 \\
\hline Moclinejo & 15 & 1271 \\
\hline Arenas & 26.3 & 1156 \\
\hline Alfarnate & 34 & 1069 \\
\hline El Borje & 24 & 930 \\
\hline Iznate & 8 & 868 \\
\hline Canillas de Albaida & 33 & 716 \\
\hline Totalán & 9.21 & 607 \\
\hline Cútar & 20 & 614 \\
\hline Sedella & 32 & 606 \\
\hline Macharaviaya & 7.24 & 480 \\
\hline Alfarnatejo & 20 & 377 \\
\hline Árchez & 4.8 & 385 \\
\hline Salares & 10 & 169 \\
\hline
\end{tabular}

Source: IECA (2020).

\section{Materials and Methods}

The research was carried out in three stages. The first consisted of a study of the wine production area of La Axarquía. The visits to this geographical area were made between April and November 2019, a method used by other researchers to learn about the reality of wine tourism in specific areas (Bruwer 2003; López-Guzmán et al. 2014). In this phase a vital issue for the structuring of the itineraries of the wine tourism route was analyzed, namely the resources and services offered.

The information obtained was completed by means of a documentary analysis using multiple sources (General Catalogue of Andalusian Historical Heritage, Catalogue of Protected Assets and Spaces of the Provincial Council of Malaga and tourist information available both in brochures and online).

The second stage consisted of an in-depth interview with winemakers and agents involved in the production of wine (Table 2), an appropriate tool for exploring the subject, as it allows for the evaluation of non-neutral knowledge (Gillis and Jackson 2002; Mason 2006; Pepper and Wildy 2009). The questionnaire was designed by a work team belonging to the SEJ 121 "Mediterráneo Económico" research group at the University of Malaga and was structured in a single section of XII questions. In order to eliminate problems of comprehension and subsequent interpretation of the data, a pilot experience was carried out by selecting four participants. The interview (Appendix A) invited participants to comment on what they believed to be the key strengths and weaknesses of the wine activity in terms of wine tourism. The authors of the responses have remained anonymous. The interview was implemented by all $100 \%$ of the winemakers, whose wineries are located in eight 
municipalities in the region. Vélez Málaga and Cómpeta hosted two wineries and the rest were distributed in the nearby towns of Árchez, Colmenar, Moclinejo, Sayalonga, Sedeya, and Torrox. Ten responses were collected from institutional representatives, managers of public and private companies, and other entities, which represented $70 \%$ of the institutional sector present in the territory of La Axarquía.

Table 2. Fact sheet of the interview.

\begin{tabular}{ll}
\hline $\begin{array}{l}\text { Data Collection } \\
\text { Method }\end{array}$ & Semi-Structured In-Depth Interviews \\
\hline Sample & $\begin{array}{l}\text { Winery owners and managers, business sector agents, representatives } \\
\text { of institutions and social agents. }\end{array}$ \\
\hline Number of interviewees & 20 \\
\hline Sampling period & April-November 2019 \\
\hline \multirow{3}{*}{ Interviewees } & Molina, Bodegas Almijara, Bodegas Luis Picante, Bodega A. Muñoz \\
& Cabrera, Bodegas Bentomiz, Sedella Vinos, Bodegas Medina y Toro, \\
& Bodegas Jorge Ordoñez \& Co., Cooperativa Unión Pasera de la \\
& Axarquía (Ucopaxa) \\
\hline & 70\% of agents: Mancomunidad Costa del Sol Axarquía (Turismo), \\
Centro de Desarrollo Rural de la Axarquía (CEDER-Axarquía), \\
Asociación para la Promoción Turística de la Axarquía (APTA), \\
Delegación Agricultura Junta Andalucía, Turismo Andaluz, \\
Asociación de Empresarios de Vélez Málaga, Asocación de \\
Empresarios de Nerja, Asociación Agraria de Jóvenes Agricultores \\
(ASAJA) Vélez Málaga, Unión de Pequeños Agricultores Axarquía \\
(UPA-Axarquía). Fundación Cueva de Nerja.
\end{tabular}

Source: own elaboration.

Once the interviews had been analyzed, a SWOT was structured to determine the real situation and define the implementation of possible wine tourism itineraries in the region of La Axarquía, a methodology already used in other studies on the development of strategies related to wine tourism (Carrà et al. 2016; de la Torre and Navarro 2008; Wilkins and Hall 2001). SWOT analysis is a multi-application tool that can be used to analyze different aspects of a strategic nature, given that it provides excellent information for decision-making. The benefit obtained with its application is the knowledge of the real conditions in which an organization finds itself, in order to assume risk and take advantage of the opportunities offered by the environment. It is important that the wine industry and the tourism industry identify and understand their key strengths, weaknesses, opportunities and threats, as well as how these factors interact, so that effective decisions can be made in terms of sustainable wine tourism development (Álvarez García et al. 2014; Millán 2012).

Thirdly, with the information available, we proceeded to make a proposal for wine tourism itineraries that take into account the needs indicated by the interviewees, as well as the heritage elements of the territory and the most necessary services for the development of the enotourism route, having in mind the findings made by the research group (Cruz-Ruiz et al. 2020), shown in Figure 1.

\section{Results}

The study of heritage resources, both tangible and intangible, tourism services and wineries present in a geographical space is valued to the extent that they provide options for progress in the form of wine tourism itineraries, taking into account the peculiarities of the territory. In this case study and in researches applied to other wine-growing areas, where wine and tourism come together (Harvey et al. 2014), where the rural is perceived as 
a space in which the land prevails as an element of production, the values, resources and culture itself promote products to discover and enjoy (Privitera 2010).

\subsection{Heritage and Services in La Axarquía}

Following the Table 3, we can observe that the material heritage has a great diversity in the region in the form of unique historical buildings, traditional architecture and monuments, representing elements that add value to the territory. Obviously, the richness of this matter is highly variable and does not necessarily correspond to the size of the municipality, hence the importance of the fieldwork carried out.

Table 3. Types of tourist resources and services offered in the municipalities of La Axarquía.

\begin{tabular}{|c|c|c|c|c|c|c|c|c|c|c|c|c|c|c|}
\hline & \multicolumn{4}{|c|}{ Tangible Heritage } & \multicolumn{5}{|c|}{ Intangible Heritage } & \multicolumn{5}{|c|}{ Services Offered } \\
\hline Heritage and Services & $\frac{\mathscr{E}}{3}$ & 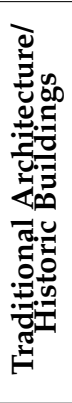 & 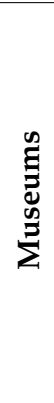 & 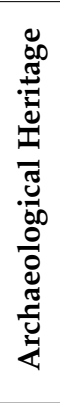 & 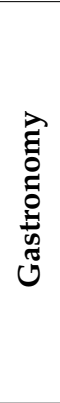 & 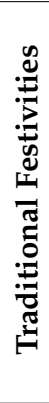 & 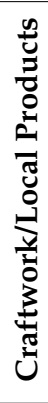 & 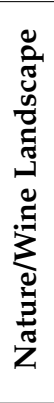 & 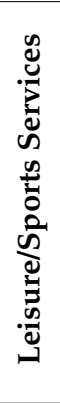 & 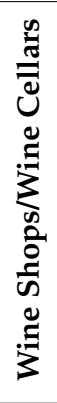 & 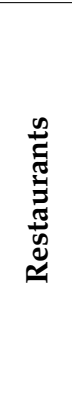 & 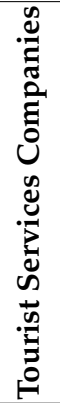 & 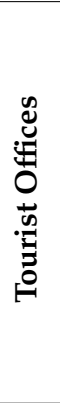 & 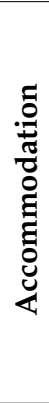 \\
\hline Vélez Málaga & 2 & $x$ & $x$ & $\mathrm{x}$ & $x$ & $x$ & $x$ & $\mathrm{x}$ & $\mathrm{x}$ & $x$ & $x$ & $x$ & $x$ & $x$ \\
\hline Rincón de la Victoria & & $x$ & $x$ & $x$ & $x$ & $x$ & $x$ & $x$ & $\mathrm{x}$ & $x$ & $x$ & $x$ & $x$ & $x$ \\
\hline Nerja & & $x$ & $x$ & $x$ & $x$ & $x$ & $x$ & $x$ & $x$ & $x$ & $x$ & $x$ & $x$ & $x$ \\
\hline Torrox & 1 & $x$ & & $x$ & $x$ & $x$ & $x$ & $x$ & $x$ & $x$ & $x$ & $x$ & $x$ & $x$ \\
\hline Algarrobo & & $x$ & & $x$ & $x$ & $x$ & & $x$ & & $x$ & $x$ & & $x$ & $x$ \\
\hline Cómpeta & 2 & $x$ & $x$ & & $x$ & $x$ & $x$ & $x$ & & $x$ & $x$ & & $x$ & $x$ \\
\hline Colmenar & 1 & $x$ & $x$ & & $x$ & $x$ & $x$ & $x$ & & $x$ & $x$ & & & $x$ \\
\hline Frigiliana & & $x$ & $x$ & & $x$ & $x$ & $x$ & $x$ & $\mathrm{x}$ & $\mathrm{x}$ & $x$ & $\mathrm{x}$ & $x$ & $x$ \\
\hline Periana & & $x$ & $\mathrm{x}$ & & $x$ & $x$ & $x$ & $x$ & $x$ & $x$ & $x$ & $x$ & & $x$ \\
\hline Benamocarra & & $x$ & & & $x$ & $x$ & & $x$ & & & $x$ & & $x$ & $x$ \\
\hline Riogordo & & $x$ & & & $x$ & $x$ & & $x$ & & & $x$ & & & $x$ \\
\hline Alcaucín & & $x$ & & $x$ & $x$ & $x$ & $x$ & $x$ & & $x$ & $x$ & & $x$ & $x$ \\
\hline La Viñuela & & $x$ & & & $x$ & $x$ & & $x$ & & $x$ & $x$ & & $x$ & $x$ \\
\hline Almáchar & & $x$ & $x$ & & $x$ & $x$ & $x$ & $x$ & & & $x$ & & & $x$ \\
\hline Sayalonga & 1 & $x$ & $x$ & & $x$ & $x$ & & $x$ & & $x$ & $x$ & & & $x$ \\
\hline Canillas de Aceituno & & $x$ & & & $x$ & $x$ & $x$ & $x$ & & & $x$ & & & $x$ \\
\hline Benamargosa & & $\mathrm{x}$ & & & $\mathrm{x}$ & $x$ & $x$ & $\mathrm{x}$ & & & $x$ & & & $x$ \\
\hline Comares & & $x$ & & $\mathrm{x}$ & $x$ & $x$ & $x$ & $x$ & & & $x$ & $x$ & $x$ & $x$ \\
\hline Moclinejo & 1 & $x$ & & & $x$ & $x$ & $x$ & $x$ & & $x$ & $x$ & & & $x$ \\
\hline Arenas & & $x$ & & & $x$ & $x$ & $x$ & $x$ & $\mathrm{x}$ & & $x$ & & & $x$ \\
\hline Alfarnate & & $x$ & $x$ & & $x$ & $x$ & $x$ & $x$ & & $x$ & $x$ & & $x$ & $x$ \\
\hline El Borje & & $x$ & & & $x$ & $x$ & $x$ & $x$ & & & $x$ & & & $x$ \\
\hline Iznate & & $x$ & & & $x$ & $x$ & $x$ & $x$ & & & $x$ & & & $x$ \\
\hline Canillas de Albaida & & $x$ & & & $x$ & $x$ & $x$ & $x$ & & & $x$ & & & $x$ \\
\hline Totalán & & $x$ & & $\mathrm{x}$ & $x$ & $x$ & $x$ & $x$ & & & $x$ & & & $x$ \\
\hline Cútar & & $x$ & & & $x$ & $x$ & $x$ & $x$ & & & & & & $x$ \\
\hline Sedella & 1 & $x$ & & & $x$ & $x$ & $x$ & $x$ & & $x$ & $x$ & & $x$ & $x$ \\
\hline Macharaviaya & & $x$ & & & $x$ & $x$ & $x$ & $\mathrm{x}$ & & & $x$ & & & $x$ \\
\hline Alfarnatejo & & $x$ & & & $x$ & $x$ & $x$ & $x$ & & & $x$ & & & $x$ \\
\hline Árchez & 1 & $x$ & & & $x$ & $x$ & $x$ & $x$ & & $x$ & $x$ & & & $x$ \\
\hline Salares & & $x$ & & & $x$ & $x$ & $x$ & $x$ & & & $x$ & & & $x$ \\
\hline
\end{tabular}

Source: Own elaboration according to IECA (IECA 2020), as well as on elements and resources of La Axarquía in the General Catalogue of Andalusian Historical Heritage and the Catalogue of Protected Assets and Spaces of the Provincial Council of Malaga. The symbol " $x$ " means that the element is present in the corresponding municipality. 
With regard to the tasks related to viticulture, heritage elements have been preserved, in particular the grape drying sheds for the production of raisins must be mentioned due to their exceptional nature. As reported by the respondents, there is a worrying and progressive process of disappearance of agricultural heritage elements, wine presses, drying sheds and warehouses, due to the updating of wine-making work and the lack of valorization of these places until recently. Some of them are part of the history of certain wine-producing localities in the territory under study.

Therefore, this vast heritage is present, to a greater or lesser extent, in all the municipalities of La Axarquía in the form of historic buildings (churches, houses, old industries, archaeological remains). As far as museums are concerned, although there are several of these infrastructures, only one of them is entirely devoted to traditional wine making. It is located in the municipality of Cómpeta. In the rest we can find and recognize some elements related to wine production, as well as archaeological, artistic or anthropological ones that illustrate the historical and patrimonial richness of the region.

In this way, the itineraries to be designed will be determined by the local wine industry and the value of its culture, contributing to sustainable development and preserving the existing rich heritage, a casuistry observed in other territories (Carrasco et al. 2019) under the model of wine tourism product club in Spain (Gomis et al. 2010).

La Axarquía has a strong sense of identity reflected in the potential of its intangible heritage. Even today, in most of its municipalities you can still find examples of traditional trades, mainly those related to agriculture and in particular those related to wine-making.

Festivals are another attraction and a perfect complement to wine tourism visits (Getz 2019; López-Guzmán et al. 2019). The cultural and ethnographic variability endows La Axarquía with a complex festive framework developed throughout the year, be it the typical patron saint feasts or other festivities and events related to the traditional tasks of wine and gastronomy, which is an added motivation for the visitor. In fact, the prominence of wine and raisins is a central theme of certain festivals usually held in the summer months, when the grapes are harvested. The municipalities with the greatest wine-growing traditions, such as Cómpeta, Moclinejo and Colmenar, are the main protagonists, although raisins and grapes are also part of the popular culture in El Borge, Iznate and La Viñuela.

The wine landscape is the most outstanding natural and genetic heritage. The tourist resource of the landscape and the vineyard offer one of the most interesting options in a wine tourism route (González Morales et al. 2015). In this sense, the vineyards of La Axarquía make up a very characteristic landscape due to the unevenness of the terrain, which makes it necessary to use mules to harvest the grapes. In addition, it is considered an economic and heritage resource, due to its determining influence on productive activities of great relevance, among which is tourism and also residential development (Almeida García and Cortés Macías 2011).

As for services, these are concentrated in the municipalities with the largest number of inhabitants and in the centers characterized by their offer of sun and beach tourism activities, such as Rincón de la Victoria, Vélez Málaga, Torrox and Nerja. Leisure services and tourist service companies are present in the aforementioned municipalities, to which are annexed Periana and Arenas, where there are companies related to active tourism.

More than a third of the municipalities in the inland of the region, apart from those on the coast, have tourist information offices, which makes them interesting stop points on the route: Cómpeta, Frigiliana, Benamocarra, Alcaucín, La Viñuela, Comares, Alfarnate and Sedella. Restaurant and accommodation services are omnipresent in all the towns. The type of accommodation is varied, ranging from the large hotels located in the coastal towns of Vélez Málaga and Nerja to the small rural hotels in municipalities such as Arenas, as well as the tourist apartments that flourish in towns such as Frigiliana and Alcaucín. In the case of restaurants, all the towns except Cútar have them and, even though the types are varied, local gastronomy is present in all of them. 


\subsection{Diagnosis of the Territory: SWOT}

The information compiled through the interviews has allowed the elaboration of a diagnosis of La Axarquía by means of a SWOT, in which the strengths and weaknesses, threats and opportunities of wine tourism in the area are specified (Table 4).

The present offer of services is based mainly on tangible elements such as wine and wineries, but there are intangible elements that add attractiveness and interest such as the surrounding elements or the associated services. The geographical context has a major influence on the analysis. In the case of La Axarquía, it has recently been transformed into an area where agriculture has given way to tourism as a source of income, becoming just another zone of the metropolitan area of Malaga, which can generate conflicts of interests that can be overcome with proper planning (Almeida García 2011).

Furthermore, it is necessary to take into account the important role played by the different local, provincial and regional public administrations in the development of the initiatives related to the construction of a certified wine route, as they require active incentive policies, as well as elements to boost the necessary infrastructures and the promotion of the territory. SWOT shows the most relevant issues for outlining the actions that can be derived from public policies to support the development of the rural territory.

Table 4. SWOT matrix on the wine sector in La Axarquía.

WEAKNESSES

STRENGTHS

- Need to adapt the wineries to the demand for wine tastings and local gastronomy.

- $\quad$ Problems of promotion and communication (marketing) of the wine tourism attractions of La Axarquía.

- Lack of interest in the world of wine among the sun and beach tourists who visit the area, as wine culture is not a priority for them.

- Lack of professional experts specialized in the richness of heritage and/or oenology.

- Inadequate indication of wine tourism points of interest.

- Lack of collaboration between the different establishments involved.

- Visually attractive agricultural landscape.

- Wide variety of tangible and intangible heritage.

- Wide variety of local events and festivities.

- Recovery of ethnographic spaces that enhance the wine itinerary.

- Wide and varied range of rural accommodation and restaurants.

- $\quad$ Deep-rooted ancestral winemaking tradition

- $\quad$ High quality of the vineyards in the area with native and endemic grape varieties.

- $\quad$ Dispersed population centers and poor land communications.

THREATS

\section{OPPORTUNITIES}

- $\quad$ Limited number of wineries with adequate infrastructures to guarantee the reception of visitors.

- Possibility of other tourist itineraries overshadowing La Axarquía itineraries.

- Progressive disappearance of the traditional wine landscape due to the introduction of non-native agricultural species.

- Small wineries with limited production volumes.

- Little dialogue between institutional authorities and winemakers.
- Willingness of public institutions to promote wine tourism as a sustainable tourism offer.

- $\quad$ Emergence of operators specializing in wine tourism

- Concern for the sustainability and survival of viticulture as an activity that provides high added value.

- Integration of La Axarquía into the Malaga and Ronda Wine Route.

- Compatibility of wine tourism with other rural and inland tourism activities.

- Differentiation through the development of a sustainable tourism product.

- $\quad$ Large number of visitors and tourists from the coast. 


\subsection{Characteristics of the Wineries and the Services Offered}

Wine tourism as an economic driver has its ultimate expression in the organization of routes and itineraries. A construction that requires institutional collaboration and the involvement of private initiatives that are channeled through the winemaking businesses in La Axarquía.

The research carried out in person in each of the wineries (Table 5) has allowed a rigorous study of their possibilities and a mapping of the characteristics of each one of them, which is essential for the elaboration of wine tourism itineraries. Table 5 shows the characteristics of the wineries in the area of La Axarquía, as well as the services they provide.

Table 5. Characteristics and services of the wineries of La Axarquía.

\begin{tabular}{|c|c|c|c|c|c|c|c|c|c|c|c|}
\hline \multirow[b]{2}{*}{ Wineries } & \multicolumn{5}{|c|}{ Characteristics } & \multicolumn{6}{|c|}{ Services } \\
\hline & Town & $\begin{array}{c}\text { Founding } \\
\text { Year }\end{array}$ & $\begin{array}{c}\text { Type of } \\
\text { Business * }\end{array}$ & $\begin{array}{l}\text { Own } \\
\text { Vine- } \\
\text { yards }\end{array}$ & Products & $\begin{array}{c}\text { Business } \\
\text { Marketing } \\
\text { Language }\end{array}$ & $\begin{array}{c}\text { Tasting/ } \\
\text { Gastronomic } \\
\text { Menu }\end{array}$ & $\begin{array}{l}\text { Direct } \\
\text { Sale of } \\
\text { Wine }\end{array}$ & $\begin{array}{l}\text { Visits } \\
\text { to Vine- } \\
\text { yards }\end{array}$ & Events & Website \\
\hline $\begin{array}{l}\text { Hermanos } \\
\text { López Martín }\end{array}$ & Archez & 1988 & Family-run & $\mathrm{x}$ & Wine & Spanish & & $x$ & & & \\
\hline José Molina & Colmenar & 2011 & Family-run & $\mathrm{x}$ & Wine & Spanish/English & $\mathrm{x}$ & & & & $\mathrm{x}$ \\
\hline Almijara & Cómpeta & 1993 & Family-run & $\mathrm{x}$ & Wine & Spanish/English & $x$ & $x$ & & & $x$ \\
\hline Luis Picante & Cómpeta & 2001 & Family-run & & Wine & Spanish & & $x$ & & & \\
\hline $\begin{array}{l}\text { A. Muñoz } \\
\text { Cabrera } \\
\text { (Dimobe) }\end{array}$ & Moclinejo & 1927 & Family-run & $x$ & Wine & Spanish/English & $x$ & $x$ & $x$ & $x$ & $x$ \\
\hline Bentomiz & Sayalonga & 2003 & Family-run & $x$ & Wine & Spanish/English & $x$ & $x$ & $\mathrm{x}$ & $\mathrm{x}$ & $\mathrm{x}$ \\
\hline Sedella Vinos & Sedella & 2006 & Family-run & $x$ & Wine & Spanish/English & $x$ & $x$ & $\mathrm{x}$ & & $\mathrm{x}$ \\
\hline Medina y Toro & Torrox & 2006 & Family-run & $\mathrm{x}$ & Wine & Spanish & $\mathrm{x}$ & $x$ & & & $\mathrm{x}$ \\
\hline $\begin{array}{l}\text { Jorge Ordoñez } \\
\& \text { Co }\end{array}$ & $\begin{array}{l}\text { Vélez- } \\
\text { Málaga }\end{array}$ & 2004 & Family-run & $x$ & $\begin{array}{l}\text { Organic } \\
\text { wine }\end{array}$ & Spanish/English & $x$ & $x$ & & $x$ & $x$ \\
\hline $\begin{array}{l}\text { Cooperativa } \\
\text { Unión Pasera } \\
\text { de la Axarquía }\end{array}$ & $\begin{array}{l}\text { Vélez- } \\
\text { Málaga }\end{array}$ & 1980 & Cooperative & $\mathrm{x}$ & Wine/Raisin & ns Spanish & & $x$ & & & $x$ \\
\hline
\end{tabular}

The predominant business structure is the family-run type, with the exception of UCOPAXA, a cooperative that brings together more than 700 farmers and which produces and markets $70 \%$ of Malaga's raisin production, making various types of wine. Most of the wineries have their own vineyards; only Bodegas Luis Picante purchases must from local producers to make its wines. With regard to wine production, the traditional production of sweet wines in the area has given way to red, rosé and white wines, which in the case of Bodegas Jorge Ordoñez are organically produced.

In the case of the wineries, the dates on which they were founded are striking, with those that began their activity at the end of the 21st century dominating the scene in the heat of the growing interest in viticulture. However, we recognize the singularity of Bodegas A. Muñoz Cabrera, known as Dimobe, founded in 1927, whose business has continued uninterruptedly since then.

Despite the fact that all the wineries are committed to wine tourism, the degree of development of services is uneven. Customer service is provided in Spanish and English, at least in most of them. Most of the wineries offer the possibility of wine tastings which can be accompanied by gastronomic menus, while visitors can buy the wines they produce directly. Wine-related events are only offered at three wineries, while vineyard tours are only available at three of the wineries. 


\section{Organization of Wine Tourism Itineraries}

Tourist routes and itineraries are nowadays a matter of great interest for the competent tourist bodies in Spain. In the case of Malaga, their existence is promoted by the Public Company of Andalusian Tourism, the Provincial Council of Malaga, and in La Axarquía by La Axarquía Rural Development Group (Grupo de Desarrollo Rural de La Axarquía, CEDER).

The wine tourism itineraries proposed for La Axarquía highlight the importance of the existing heritage resources and services. The opinions gathered among the agents involved point to the existence of numerous routes of tourist interest which can be based on the attractions of the area. The interviewees acknowledged the existence of some institutional initiatives, although they have not had a significant impact on the localities along the routes.

With regard to an enotourism route or itinerary, it must have a layout that brings together specific resources and that meets the criteria of efficiency and economic profitability. Assuming these criteria in a geographical, cultural and historical context linked to wine, two different wine tourism route/itinerary options are proposed, taking into account environmental sustainability criteria, placing value on the tangible and intangible elements it possesses and combining the efforts of social and institutional agents, private companies, producers and consumers.

After having catalogued the elements present in the region of La Axarquía useful for the definition of a wine tourism route, having validated them through a field study and the interviews in the SWOT matrix, we believe that it is possible to propose two wine itineraries in La Axarquía. Logically, the role played by the wineries is fundamental, especially those that are more closely linked to the wine tradition or those that show a greater interest in being linked to the wine tourism route.

These itineraries try to create a coherent visit, in which the greatest number of heritage elements and services are present, taking into account the mandatory inclusion of the wineries, which work as a critical element and must necessarily be included in the itinerary. The density of heritage elements complicates the route, as almost any corner of the territory is worth a visit. Services are another of the keys to success. The restaurant offer covers almost all the municipalities, with interesting proposals that recover the local culinary heritage and modernize it, while the local wines have an important presence in bars, restaurants and in the few wine cellars in the area. There is a wide range of possibilities for overnight stays in the area, thanks to the large network of rural accommodation available in most of the municipalities.

\section{- 1st Proposed Itinerary}

The first itinerary aims to showcase the largest number of wineries in La Axarquía, as well as its heritage elements (Figure 3). It is a circular route that starts and ends in Vélez Málaga, which is the municipality where the visitor can find the largest offer of accommodation and which is easily accessible from the A-7 motorway, which connects with the city of Malaga in $30 \mathrm{~min}$. Vélez Málaga is the head of the region of La Axarquía and is home to two wineries, Jorge Ordóñez \& Co. and Ucopaxa, the latter also dedicated to the marketing of raisins.

There is a wide range of heritage and services on offer, and it is worth highlighting the heritage that is concentrated in the historic center. The direction of the route does not affect the visit, so the first point of interest is Bodegas Medina y Toro, located in Torrox, a municipality that is divided between the coastal strip and Almijara mountain range and that is organized along the axis marked by the river Torrox. This town has a historical and archaeological heritage that dates back to the time of the Roman colonization and includes important remains of industrial activities such as the San Rafael sugar factory. The next milestone on the route is the town of Cómpeta, which stretches along the southern slopes of Sierra Almijara to the Montes de Málaga, with a landscape of hills covered with vineyards, olive groves, almond trees and scrubland. The town is especially known for 
$2 \mathrm{~km}$
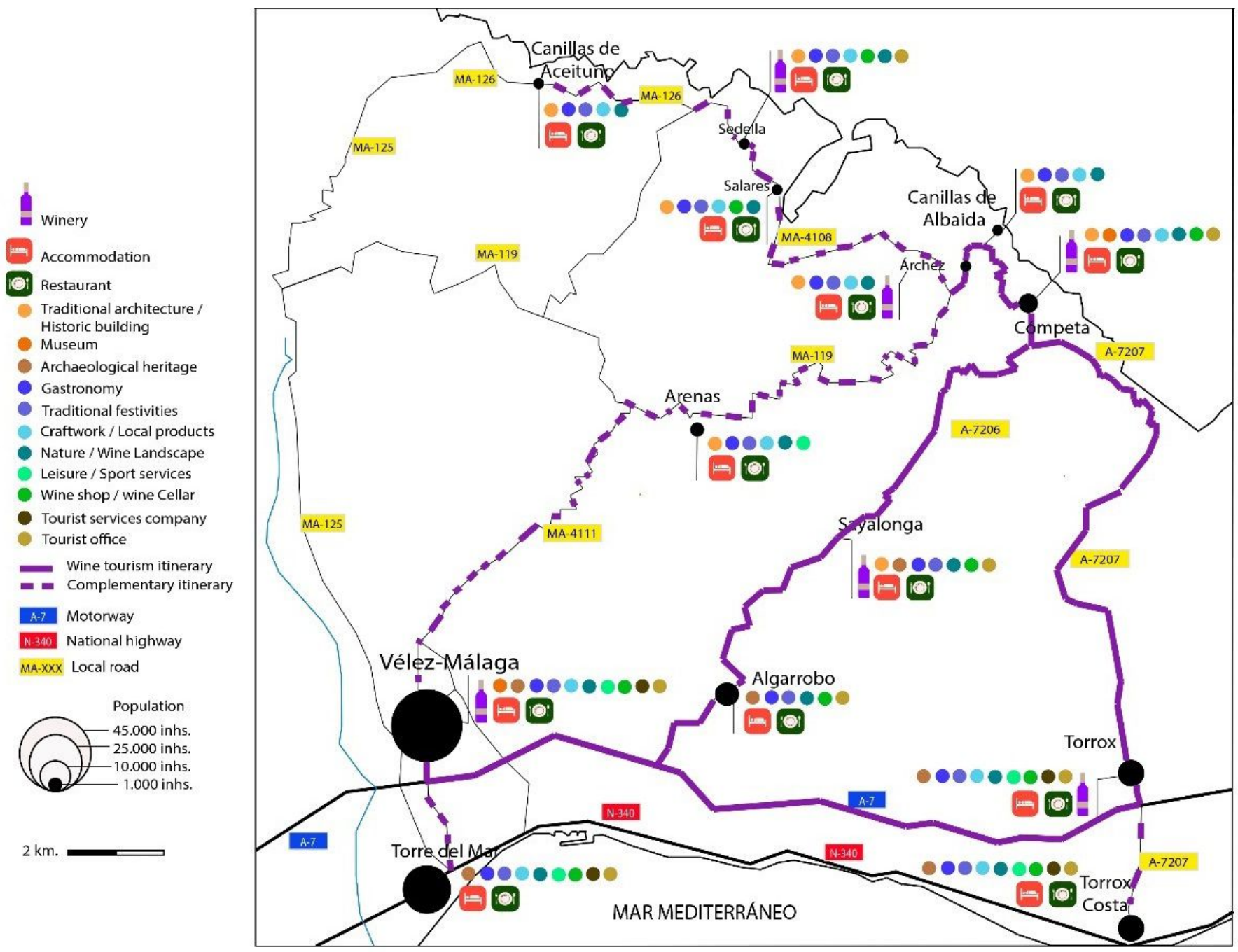

its wine-growing tradition and culture and is home to Bodegas Luis Picante and Bodegas Almijara. Numerous heritage elements can be found (the cemetery of San Sebastián and its historic quarter stand out), as well as popular festivals.

Traditional work has also been preserved, apart from the work of the vineyard, which is still practiced today, such as the lime industry and tinplate craftwork. The next point on the route is Árchez, a small town at the foot of Sierra Tejeda, surrounded by vines and olive trees and which preserves a minaret of Muslim origin. In this town you can visit the Hermanos López Martín winery, whose main interest lies in the surrounding landscape and ethnographic values.

The route can be extended to Sedella, a municipality of singular interest that treasures an interesting popular architecture and where traditional crafts such as imagery and esparto grass work are still preserved. Sedella Vinos winery is responsible for keeping alive the town's winemaking tradition, where the mountain landscape and the vineyards, olive and almond groves coexist. The return is from Cómpeta in the direction of Sayalonga on the A-7206. This small municipality of steep slopes is home to Bodegas Bentomiz, ending the route back in Vélez Málaga.

Figure 3. Own elaboration based on the Digital Cartography of Andalusia (IECA). Location map of Itinerary \#1. La Axarquía (Malaga, Spain). ETRS89 UTM 30S. 
The second itinerary takes in what is known as the Raisin Route, which has an interesting heritage value, both tangible and intangible (Figure 4). It highlights the vineyard landscape in a steeply sloping terroir that extends over the hills of the Montes de Málaga and where the traditional grape drying sheds are also located. The route can be followed in either direction, and if you take the possible extension to El Rincón de la Victoria, it is a circular route. The possibilities for overnight stays in the area are varied, especially in terms of rural accommodation.

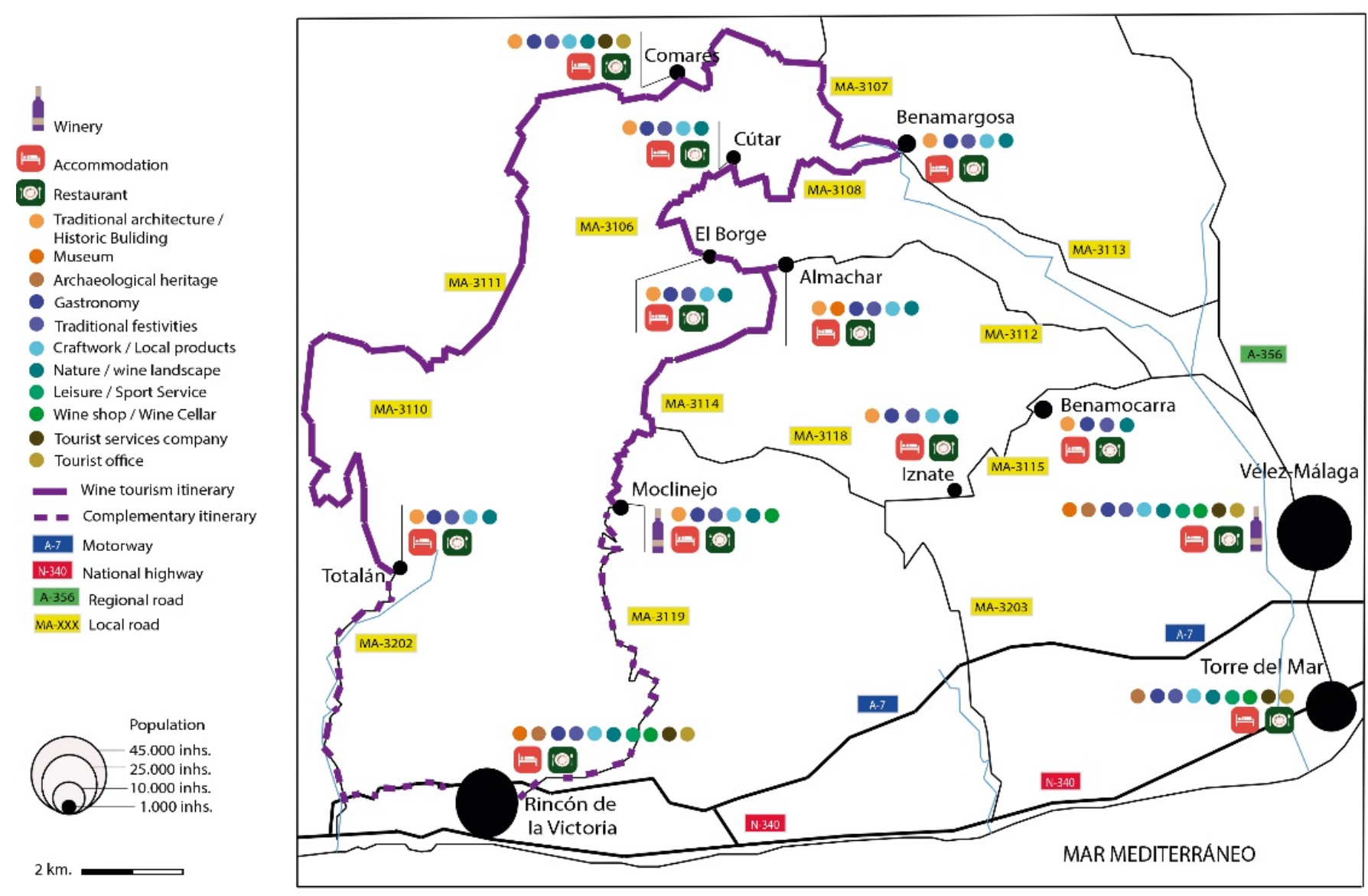

Figure 4. Own elaboration based on the Digital Cartography of Andalusia (IECA). Location map of Itinerary \#2. La Axarquía (Malaga, Spain). ETRS89 UTM 30S.

Starting from Moclinejo, it is there where you can visit Bodegas Muñoz Molina, the only establishment dedicated to the production of wine along the route. The next point of interest is Almáchar, situated on a hill located between the rivers El Borge and Almáchar and here, from the end of August, you can observe the process of drying the grapes to produce raisins. Other activities of interest are the festivals and popular celebrations around the livestock activity and the typical products of the area such as "ajoblanco". A short distance away is El Borge, a municipality that is clustered around the Ejido hill, on the banks of the river from which the town takes its name. The urban center is integrated into the landscape with a structure of winding streets adapted to the relief of the area. Of interest are several heritage elements such as the cemetery, the parish church and two old mills. The traditional activities of grape harvesting and processing are still common among the inhabitants. The route now heads towards the small town of Cútar, which spreads out on a hill of the same name, dominating the surrounding valley. It is worth mentioning some heritage elements linked to economic activities, such as mills and fountains. Apart from the wine-growing activity, traditional trades such as esparto and basket weaving are still preserved. The route continues to Benamargosa, which takes its name from the river that runs through it and which allows the development of orchards where citrus and avocado 
trees are grown, blending in with the vineyard landscape. Comares is the next point on the route, located on the hill from which it takes its name. Its geographical conditions made it an excellent defence post, especially during the period of Moorish rule. It is around the fortifications of this period that the historic quarter is clustered, with its typical Moorish urban layout, which is completely pedestrianized due to the narrowness and steepness of the streets. There are numerous heritage elements, some of which are linked to the defensive function of the town or to religious worship, as well as those of a civil nature. Of particular note is the folkloric expression of the Verdiales, a style of fandango typical of the province of Malaga, which takes its name from this locality in one of its styles and which is danced in its popular festivals. The route ends in Totalán, a small municipality adjoining the town of Málaga, which adapts to the terrain and takes advantage of the waters of the stream of the same name that runs through the town. The urban layout denotes its Moorish origins, although the area has been inhabited since prehistoric times.

\section{Discussion}

In recent decades, the rural world has been undergoing profound social and economic changes in many territories, joining a global and intensely interconnected world and demanding a better exploitation of its resources, among which wines are particularly important (Baird et al. 2018; Brunori and Rossi 2000). In this context, wine tourism and, more specifically, wine routes and itineraries, are a way that reflects the consumption patterns of tourists seeking leisure experiences that are close to and adapted to their lifestyles.

Sensitivity to environmental values, sustainability and the search for authenticity through cultural and landscape elements are an important asset for the economic development of rural wine-growing areas, as tourists are willing to pay to discover new experiences far from the overcrowding of traditional holiday destinations (Cristófol et al. 2020; Pulpón and Ruiz 2019). In fact, public and private actors in La Axarquia have undertaken sustainability policies both in coastal areas and in the rural territory.

In the case of Spain, ACEVIN plays a transcendental role in improving the wine tourism offer in places with a great wine tradition, promoting quality tourism. In recent times, numerous routes have been set up, such as the Ronda and Malaga route (including the territory of La Axarquia), which is just beginning its journey and represents a great business opportunity for each of its tours (Vázquez Palmero et al. 2017; Ruiz-Romero de la Cruz et al. 2017).

Wine and wineries are the central axis that articulates the exploitation of this tourist segment. Therefore, these businesses should organize tastings and guided tours in which the singularities of Malaga's wines and their production methods are made known. However, a wine tour contains more elements, so special attention must be paid to accommodation, restaurants, complementary tourist activities, infrastructures (Alberdi Collantes 2018; Asero and Patti 2009; Festa et al. 2020), as well as to an adequate availability of information about the destination (websites, maps, brochures and tourist documentation) (Cassar et al. 2018).

\section{Conclusions and Implications}

The research has examined the resources and services available in the region of La Axarquía to create itineraries that represent an undoubted opportunity for economic diversification that can have a direct impact on the economy, fulfilling the objectives promoted by UNESCO to enhance the value of local heritage. Some of these wineries with a long tradition in the family business will play a fundamental role in the development of the wine tourism itineraries, satisfying a demand from wine tourists who are looking for a unique experience during their visit, as well as the opportunity to discover vineyards, wine landscapes, traditions and local festivities. Some of the wineries in La Axarquía have made an important updating effort, organizing visits to their vineyards, as well as wine and local gastronomy tastings, favoring the dissemination of Spanish wine culture. 
The planning and organization of wine tourism and the collaboration between institutions and companies are necessary in order to correct the imbalances that are being generated by the massive offer of sun and beach in the coastal area, concentrated in certain coastal municipalities such as Rincón de la Victoria, Torre del Mar, Torrox Costa and Nerja. The diversion of the flow of visitors towards a quality and sustainable tourist activity must take into account the inherent limitations of the region in terms of environmental pressure, capacity and preservation of the natural environment, as well as a landscape that gives it a unique identity. At present, the flow of visitors makes short trips to the production areas, responding to a need to "discover" the values of the interior of the region and showing its capacity to concentrate its visits on weekends and short holiday periods.

The research findings highlight the importance of promoting quality wine production and its landscape as distinctive tourism resources, favoring the creation of a brand image and a transversal territorial discourse that local agents perceive as one of the most important factors of the necessary rural development in this environment.

Wine routes are perceived as an opportunity for sustainable economic development and as an opportunity for synergy between wine, natural landscape and cultural heritage. The strategy to be followed involves the appropriate management of resources with the aim of rebalancing the tourist area of the region, a measure aimed at the specialization of tourist resources by means of their enhancement through the creation of facilities for their enjoyment, recognition and sustainable management.

One of the most critical aspects of this work is the need to involve the local community, so that they feel represented and participate in the whole process of setting up an enotourism route, something that worries most of the interviewees.

The region of La Axarquía meets all the conditions to become a successful wine destination, which is why the role of the institutions must be very active, allocating resources for training and support for emerging service companies, as well as promotion through the mechanisms available to the different bodies, providing both technical and economic resources to the companies involved.

The results of the study are specific to a particular region and therefore cannot be generalized, but the conclusions can be useful for the actors responsible for the development of an economic sector as important as tourism, as well as opening a path for research into the development of future wine routes.

The field study and, in particular, the interviews with the agents and winemakers have highlighted the interest in starting or continuing a new line of business, which goes beyond the interest in marketing a wine product. They are aware of the need to promote wine tourism in the area as a way of developing the rural territory and making their businesses profitable. Adaptations to the needs of regulated wine tourism are not homogeneous and are at different stages, depending on the interest and impulse of the owners. An awarenessraising effort on the part of the institutions that we believe would result in greater tourism benefits for the area and for their own businesses.

The case study has led to a proposal for the layout of two possible wine itineraries conceived with criteria of efficiency and sustainability, which can favor the progress of La Axarquía, achieving one of the main objectives of the development of the rural territory, as well as economic and socio-cultural effects. The wine route in La Axarquía is based on a unique and specific tourist product, for which we establish a series of suggestions:

- Visit and participation in the harvesting and winemaking process.

- Training of wine tasting experts.

- Training of experts in local heritage and culture.

- Increased complementary offer (events, active tourism, cultural tourism, gastronomic tourism).

- Improvement of road infrastructures.

- Active promotion of the destination and improvement of the information available.

- Creation of a specific and distinctive markers of the route and of all the elements likely to be attractive to visitors. 
- Improving the online presence of the wineries and the possibilities offered by social networks.

- Improving of private and institutional collaboration.

- Commitment to the production of organic wines

In general, we believe that the link between wine businesses and those whose existence is based on raisins, as is the case in Malaga, should collaborate closely and could even participate jointly in the future design of tourist routes with both elements as essential resources to promote the tourist development of the rural territory in this area. It would be a unique specialization that would reinforce their identity in the marketing of new tourist products. In fact, the very structure of the Ronda and Malaga wine route is covered by the Regulatory Council of the Designation of Origin, which includes both wines and raisins. Future studies and actions on the territory should take into account the heritage elements and relate them to the sustainability of the territory as a way to generate wealth in the terroir.

Author Contributions: Conceptualization, E.R.-R.d.l.C. and G.Z.-A.; methodology, E.C.-R. and G.Z.A.; software, G.Z.-A.; validation, E.R.-R.d.l.C., E.C.-R. and G.Z.-A.; formal analysis, E.C.-R. and E.R.-R.d.l.C.; investigation, G.Z.-A. and E.C.-R.; resources, E.C.-R.; data curation, E.R.-R.d.1.C. and G.Z.-A.; writing—original draft preparation, E.R.-R.d.l.C. and G.Z.-A.; writing—review and editing, E.C.-R. and E.R.-R.d.l.C.; visualization, G.Z.-A. and E.R.-R.d.l.C. All authors have read and agreed to the published version of the manuscript.

Funding: This research received no external funding.

Acknowledgments: We would like to thank all respondents for their kind cooperation for our questionnaires and the members of SEJ-121 and the University of Malaga (UMA) for their support.

Conflicts of Interest: The authors declare no conflict of interest.

\section{Appendix A}

Model interview with winemakers and stakeholders

Name:

Position:

Institution/company:

Date:

Ref:

1. Do you think it would be interesting for La Axarquía to have its own itinerary in the Malaga Wine Route?

2. What needs do you detect in La Axarquía in order to promote it as a tourist destination?

3. Do you think that the current offer of La Axarquía is interesting for tourists?

4. Are the resources and services of La Axarquía sufficient to attract wine tourists?

5. What problems do you detect in La Axarquía related to the wine tourism activity?

6. How would you qualify the offer of tourist accommodation in La Axarquía?

7. What should be the involvement of the wineries in the wine route?

8. Is the involvement of the private agents and institutions of La Axarquía in the implementation of the certified wine route adequate?

9. Do you think that a sustainable wine tourism offer can be designed in La Axarquía?

10. Do you think that the wine tourism itineraries are compatible with other existing activities?

11. Do you think that the service providers of La Axarquía are sufficiently involved with the new wine tourism route?

12. Do you think that the new wine tourism itineraries will have an economic impact on the development of La Axarquía? 


\section{References}

ACEVIN. 2020. Asociación Española de Ciudades Del Vino. Available online: https:/ /www.acevin.es/ (accessed on 3 February 2020). Alant, Karin, and Johan Bruwer. 2004. Wine Tourism Behaviour in the Context of a Motivational Framework for Wine Regions and Cellar Doors. Journal of Wine Research 15: 27-37. [CrossRef]

Alberdi Collantes, Juan Cruz. 2018. The Prestige of the Brand and Tourism Promotion, the Keys to Success of Wine Route Rioja Alavesa. Lurralde: Investigacion y Espacio 41: 5-32.

Almeida García, Fernando, and Damián López Cano. 2003. La Costa Del Sol Oriental: Un Conflicto Territorial Entre El Turismo, La Agricultura y La Urbanización Metropolitana. Baética: Estudios de Arte, Geografía e Historia 25: 67-80. [CrossRef]

Almeida García, Fernando, and Rafael Cortés Macías. 2011. Transformaciones Urbanísticas y Territoriales En La Costa Del Sol Oriental: Otra Costa Del Sol Occidental? In Geografía y Desafíos Territoriales En El Siglo XXI. Madrid: Asociación Española de Geografía, pp. 15-28.

Almeida García, Fernando. 2011. La Costa Del Sol Oriental Como Un Estudio de Un Conflicto Territorial: La Planificación Ambiental Frente a La Urbanización. Málaga: Servicio de Publicaciones e Intercambio Científico de la Universidad de Málaga.

Alonso, Abel Duarte, and Yi Liu. 2012. Visitor Centers, Collaboration, and the role of Local Food and Beverage as Regional Tourism Development Tools: The Case of the Blackwood River Valley in Western Australia. Journal of Hospitality and Tourism Research 36: 517-36. [CrossRef]

Álpizar, Víctor Adrian, and María Magdalena Maldonado. 2009. Integración de La Ruta Del Vino En Querétaro, Un Producto Innovador. Quivera 11: 97-109.

Álvarez García, José, María de la Cruz Del Rio Rama, Jose Luís Coca Pérez, and Juan Manuel González Sanmartín. 2014. Turismo enológico y ruta Del Vino Del Riberiro En Galicia-España. Estudios y Perspectivas en Turismo 23: 706-29.

Arnáiz, Marta Martínez, Eugenio Baraja Rodríguez, and Fernando Molinero Hernando. 2019. UNESCO Criteria for the Declaration of Viticultural Regions as Cultural Landscape. Its Application to the Spanish Case. Boletin de la Asociacion de Geografos Espanoles. [CrossRef]

Asero, Vincenzo, and Sebastiano Patti. 2009. From Wine Production to Wine Tourism Experience: The Case of Italy. American Association of Wine Economists 386: 1-18.

Baird, Tim, C. Michael Hall, and Pavel Castka. 2018. New Zealand Winegrowers Attitudes and Behaviours towards Wine Tourism and Sustainable Winegrowing. Sustainability 10: 797. [CrossRef]

Bessière, Jacinthe, Jean-Pierre Poulain, and Laurence Tibère. 2013. Lálimentation Au Coeur Du Voyage. Le Rôle Du Tourisme Dans La Valorisation Des Patrimoines Alimentaires Locaux. Paris: Turisme et Recherche, pp. 71-82.

Blum, Jeffrey R., Alexander Eichhorn, Severin Smith, Michael Sterle-Contala, and Jeremy R. Cooperstock. 2014. Real-Time Emergency Response: Improved Management of Real-Time Information during Crisis Situations. Journal on Multimodal User Interfaces 8 : 161-73. [CrossRef]

Brás, José Miguel, Carlos Costa, and Dimitrios Buhalis. 2010. Network Analysis and Wine Routes: The Case of the Bairrada Wine Route. Service Industries Journal 30: 1621-41. [CrossRef]

Brunori, Gianluca, and Adanella Rossi. 2000. Synergy and Coherence through Collective Action: Some Insights from Wine Routes in Tuscany. Sociologia Ruralis 40: 409-23. [CrossRef]

Bruwer, Johan, and Edith Rueger-Muck. 2019. Wine Tourism and Hedonic Experience: A Motivation-Based Experiential View. Tourism and Hospitality Research 19: 488-502. [CrossRef]

Bruwer, Johan, and Karin Alant. 2009. The hedonic nature of wine tourism consumption: An experiential view. International Journal of Wine Business Research. [CrossRef]

Bruwer, Johan. 2003. South African Wine Routes: Some Perspectives on the Wine Tourism Industry's Structural Dimensions and Wine Tourism Product. Tourism Management 24: 423-35. [CrossRef]

Buhalis, Dimitrios, and Peter O'Connor. 2005. Information Communication Technology Revolutionizing Tourism. Tourism Recreation Research 30: 7-16. [CrossRef]

Carlsen, Jack, and Philipp Boksberger. 2015. Enhancing Consumer Value in Wine Tourism. Journal of Hospitality and Tourism Research 39: 132-44. [CrossRef]

Carlsen, Jack. 2004. A Review of Global Wine Tourism Research. Journal of Wine Research 15: 5-13. [CrossRef]

Carlsen, Jack. 2011. Assessing Service Quality at Wineries and Cellar Doors through Service Mapping. International Journal of Wine Business Research. [CrossRef]

Carlsen, Jack, and Stephen Charters. 2006. Global wine tourism: Research, amnagement and marketing. Wallingford: CABI. [CrossRef]

Carmichael, Barbara A., and Donna M. Senese. 2012. Competitiveness and Sustainability in Wine Tourism Regions: The Application of a Stage Model of Destination Development to Two Canadian Wine Regions. In The Geography of Wine: Regions, Terroir and Techniques. Dordrecht: Springer. [CrossRef]

Carrà, Giuseppina, Mariagiulia Mariani, Ivana Radić, and Iuri Peri. 2016. Participatory strategy analysis: The case of wine tourism business. Agriculture and Agricultural Science Procedia 8: 706-12. [CrossRef]

Carrasco, Inmaculada, Juan-Sebastián Castillo-Valero, and Ana Pérez-Luño. 2019. Wine Tourism and Wine Vacation as a Cultural and Creative Industry: The Case of the Bullas Wine Route. Cham: Springer. [CrossRef]

Carrión-García, Benedicto. 2015. Mancomunidad de Municipios Costal Del Sol Oriental-Axarquía. University of Málaga. Available online: https: / riuma.uma.es/xmlui/handle/10630/11331 (accessed on 17 November 2019). 
Cassar, Mario L., Albert Caruana, and Jirka Konietzny. 2018. Positioning Narratives of Wine Tourism Websites: A Lexical Analysis across Two Different Regions. Journal of Wine Research 29: 49-63. [CrossRef]

CERVIM. 2020. CERVIM. Available online: http:/ / www.cervim.org/es/cervim-presentaci-n.aspx (accessed on 6 May 2020).

Charters, Steve, and Jane Ali-Knight. 2002. Who Is the Wine Tourist? Tourism Management 23: 311-19. [CrossRef]

Chiodo, Emilio, Luigi Giordano, Jody Tubi, and Rita Salvatore. 2020. Wine Routes and Sustainable Social Organization within Local Tourist Supply: Case Studies of Two Italian Regions. Sustainability 12: 9388. [CrossRef]

Coros, Monica Maria, Ana Monica Pop, and Andrada Ioana Popa. 2019. Vineyards and Wineries in Alba County, Romania towards Sustainable Business Development. Sustainability 11: 4036. [CrossRef]

Crespi-Vallbona, Montserrat, and Oscar Mascarilla-Miró. 2020. Wine Lovers: Their Interests in Tourist Experiences. International Journal of Culture, Tourism, and Hospitality Research. [CrossRef]

Cristófol, F. J., Gorka Zamarreño-Aramendia, and Jordi de-San-Eugenio-Vela. 2020. Effects of Social Media on Enotourism. Two Cases Study: Okanagan Valley (Canada) and Somontano (Spain). Sustainability 12: 6705. [CrossRef]

Cruz-Ruiz, Elena, Gorka Zamarreño-Aramendia, and Elena Ruiz-Romero de la Cruz. 2020. Key Elements for the Design of a Wine Route. The Case of La Axarquía in Málaga (Spain). Sustainability 12: 9242. [CrossRef]

da Silva, A. Lavrador, M. João Fernão-Pires, and F. Bianchi-de-Aguiar. 2018. Portuguese Vines and Wines: Heritage, Quality Symbol, Tourism Asset. Ciencia e Tecnica Vitivinicola 33: 31-46. [CrossRef]

De Uña-Álvarez, Elena, and Montserrat Villarino-Pérez. 2019. Linking Wine Culture, Identity, Tourism and Rural Development in a Denomination of Origin Territory (NW of Spain). Cuadernos de Turismo 44: 93-110. [CrossRef]

Díaz Armas, Ricardo Jesús. 2008. Potencialidad e Integración Del ‘Turismo Del Vino’ En Un Destino de Sol y Playa: El Caso de Tenerife. PASOS Revista de Turismo y Patrimonio Cultural 6: 199-212. [CrossRef]

Dougherty, Percy H. 2012. The Geography of Wine: Regions, Terroir and Techniques. Berlin: Springer Science \& Business Media. [CrossRef]

Elias Pastor, Luis Vicente. 2006. Documentos de estudios de ocio El Turismo Del Vino. Otra Experiencia de Ocio. Bilbao: Universidad de Deusto, Available online: http:/ /www.deusto-publicaciones.es/deusto/pdfs/ocio/ocio30.pdf (accessed on 18 April 2020).

Etcheverria, Olivier. 2015. Wine Tourism and Gastronomy. In Wine and Tourism: A Strategic Segment for Sustainable Economic Development. London: Routledge. [CrossRef]

Famularo, Biagio, Johan Bruwer, and Elton Li. 2010. Region of Origin as Choice Factor: Wine Knowledge and Wine Tourism Involvement Influence. International Journal of Wine Business Research. [CrossRef]

Fernández Portela, Julio, and María Jesús Vidal Domínguez. 2020. Las Rutas Del Vino Como Motores de Dinamización Socio-Territorial: El Caso de Castilla y León. Boletín de la Asociación de Geógrafos Españoles. [CrossRef]

Ferreira, Sanette L.A., and Caitlin A. Hunter. 2017. Wine Tourism Development in South Africa: A Geographical Analysis. Tourism Geographies 19: 676-98. [CrossRef]

Festa, Giuseppe, S.M. Riad Shams, Gerardino Metallo, and Maria Teresa Cuomo. 2020. Opportunities and Challenges in the Contribution of Wine Routes to Wine Tourism in Italy-A Stakeholders' Perspective of Development. Tourism Management Perspectives 33: 100585. [CrossRef]

Fountain, Joanna. 2018. The wine tourism experience in New Zealand: An investigation of Chinese visitors' interest and engagement. Tourism Review International 22: 67-79. [CrossRef]

Gammack, John G. 2009. Wine Tourism and Sustainable Development in Regional Australia. Global Wine Tourism: Research, Management and Marketing, 59-66. [CrossRef]

Garibaldi, Roberta, Matthew J. Stone, Erik Wolf, and Andrea Pozzi. 2017. Wine Travel in the United States: A Profile of Wine Travellers and Wine Tours. Tourism Management Perspectives 23: 53-57. [CrossRef]

Gatti, Silvia, and Fabrizio Incerti. 1997. The Wine Routes as an Instrument for the Valorisation of Typical Products and Rural Areas. Paper presented at 52nd EAAE Seminar: Typical and Traditional Productions: Rural Effect and Agro-Industrial Problems, Parma, Italy, June 19-21; pp. 213-24.

Getz, Donald, and Graham Brown. 2006. Critical Success Factors for Wine Tourism Regions: A Demand Analysis. Tourism Management 27: 164-58. [CrossRef]

Getz, Donald, Jack Carlsen, Graham Brown, and Mark Havitz. 2007. Wine Tourism and Consumers. Tourism Management: Analysis, Behaviour and Strategy. [CrossRef]

Getz, Donald. 2000. Explore Wine Tourism: Management, Development and Destinations. Putnam Valley: Cognizant Communication Corporation.

Getz, Donald. 2019. Wine and Food Events: Experiences and Impacts. In Wine Tourism Destination Management and Marketing. Cham: Palgrave Macmillan. [CrossRef]

Gillis, Angela, and Winston Jackson. 2002. Research Methods for Nurses: Methods and Interpretation. Philadelphia: Davis Company.

Gomis, Francisco José Del Campo, David López Lluch, José Miguel Sales Civera, Asunción M Agulló Torres, Margarita Brugarolas, Mollá-Bauzá, África Martínez Poveda, Fermín Camacho de los Ríos, and Antonio Miguel Nogués Pedregal. 2010. Wine Tourism Product Clubs as a Way to Increase Wine Added Value: The Case of Spain. International Journal of Wine Research 2010: 27-34. [CrossRef]

González Morales, Alejandro, Antonio Ángel Ramón Ojeda, and Santiago Hernández Torres. 2015. El Cultivo Del Viñedo Como Recurso Turístico Cultural: El Caso de La Geria (Lanzarote. Islas Canarias, España). Papeles de Geografía 61: 109-21. [CrossRef] 
Hall, C. Michael, and Richard Mitchell. 2000. Wine Tourism in the Mediterranean: A Tool for Restructuring and Development. Thunderbird International Business Review 42: 445-65. [CrossRef]

Hall, C. Michael, Liz Sharples, Brock Cambourne, Niki Macionis, and David J. Telfer. 2019a. The Northeast Wine Route: Wine Tourism in Ontario, Canada and New York State. Wine Tourism Around the World. [CrossRef]

Hall, C. Michael, Liz Sharples, Brock Cambourne, Niki Macionis, and C. Michael Hall. 2019b. Wine Tourism in New Zealand. Wine Tourism Around the World. [CrossRef]

Harvey, Matt, Leanne White, and Warwick Frost. 2014. Wine and Identity: Branding, Heritage, Terroir. London: Routledge. [CrossRef]

Hashimoto, Atsuko, and David J. Telfer. 2013. Positioning an Emerging Wine Route in the Niagara Region: Understanding the Wine Tourism Market and Its Implications for Marketing. Wine, Food, and Tourism Marketing. [CrossRef]

Holland, Tara, Barry Smit, and Gregory V. Jones. 2014. Toward a Conceptual Framework of Terroir Tourism: A Case Study of the Prince Edward County, Ontario Wine Region. Tourism Planning and Development 11: 275-91. [CrossRef]

Holmes, Mark Robert. 2017. Integrated rural wine tourism: A case study approach. Journal of Wine Research 28: 216-38. [CrossRef]

IECA. 2020. Estadísticas de Población. Available online: http:/ / www.juntadeandalucia.es/institutodeestadisticaycartografia/temas / est/tema_poblacion.htm (accessed on 7 July 2020).

Ilieş, Dorina Camelia, Aurelia Onet, Seedou Mukthar Sonko, Alexandru Ilieş, Mamadou Diombera, Ovidiu Gaceu, Ștefan Baias, Marin Ilieş, Zharas Berdenov, Grigore Herman, and et al. 2020. Air quality in cellars: A case of study of wine cellar in Salacea, Romania. Folia Geographica 62: 158-173.

Johnson, Ray, and Johan Bruwer. 2007. Regional Brand Image and Perceived Wine Quality: The Consumer Perspective. International Journal of Wine Business Research. [CrossRef]

Khartishvili, Lela, Andreas Muhar, Thomas Dax, and Ioseb Khelashvili. 2019. Rural Tourism in Georgia in Transition: Challenges for Regional Sustainability. Sustainability 11: 410. [CrossRef]

Kirkman, A., J. W. Strydom, and C. Van Zyl. 2013. Stellenbosch Wine Route Wineriers: Management's Perspective on the Advantages and Key Success Factors of Wine Tourism. Southern African Business Review 17: 93-112.

Koch, Jasmine, Andrew Martin, and Robert Nash. 2013. Overview of Perceptions of German Wine Tourism from the Winery Perspective. International Journal of Wine Business Research. [CrossRef]

López-Guzmán, Tomás, Aurea Vieira-Rodríguez, and Juan Rodríguez-García. 2014. Profile and Motivations of European Tourists on the Sherry Wine Route of Spain. Tourism Management Perspectives 11: 63-68. [CrossRef]

López-Guzmán, Tomás, Jesús C. Pérez-Gálvez, and Guzmán A. Muñoz-Fernández. 2019. A Quality-of-Life Perspective of Tourists in Traditional Wine Festivals: The Case of the Wine-Tasting Festival in Córdoba, Spain. In Best Practices in Hospitality and Tourism Marketing and Management. Cham: Springer. [CrossRef]

López-Guzmán, Tomás, Sandra María Sánchez Cañizares, and Rodríguez García. 2009. Wine Routes in Spain: A Case Study. Tourism 57: 421-34. [CrossRef]

Lourenço-Gomes, Lina, Lígia M.C. Pinto, and João Rebelo. 2015. Wine and Cultural Heritage. the Experience of the Alto Douro Wine Region. Wine Economics and Policy 4: 78-87. [CrossRef]

Lucena, Diego. 2007. Axarquía. Geografía Humana y Económica. Málaga: CEDER Axarquía, Available online: http://apta. axarquiacostadelsol.org/geografia-humana-y-economica-de-la-axarquia-pdf/ (accessed on 17 November 2019).

Marzo-Navarro, Mercedes, and Marta Pedraja-Iglesias. 2009. Profile of a Wine Tourist and the Correspondence between Destination and Preferred Wine: A Study in Aragon, Spain. Journal of Travel and Tourism Marketing 67: 670-87. [CrossRef]

Mason, Jennifer. 2006. Mixing Methods in a Qualitatively Driven Way. Qualitative Research 6: 9-25. [CrossRef]

McGregor, Arwen, and Richard N. Robinson. 2019. Wine industry and wine tourism industry collaboration: A typology and analysis. In Wine Tourism Destination Management and Marketing. Santa Lucia: Palgrave Macmillan, pp. 381-97.

Medina, Francisco Xavier, and Jordi Tresserras Juan. 2008. “Turismo Enológico y Rutas Del Vino En Cataluña: Análisis de Casos: D.O. Penedès, D.O. Priorat y D.O. Montsant. PASOS Revista de Turismo y Patrimonio Cultural. [CrossRef]

Michael Hall, C. 2013. Wine, Food, and Tourism Marketing. London: Routledge. [CrossRef]

Millán Vázquez de la Torre, Genoveva, and Leonor M Pérez. 2014. Comparación Del Perfil de Enoturistas y Oleoturistas En España. Un Estudio de Caso. Cuadernos de Desarrollo Rural 11: 167-88. [CrossRef]

de la Torre, Genoveva Millán Vázquez, and Amparo Melián Navarro. 2008. Rutas Turísticas Enológicas y Desarrollo Rural. El Caso Estudio de La Denominación de Origen Montilla-Moriles En La Provincia de Córdoba. Papeles de Geografía 47-48: 159-70. [CrossRef]

Millán, Genoveva. 2012. Las Denominaciones de Origen y Las Rutas Del Vino En España: Un Estudio de Caso. Rotur: Revista de Ocio y Turismo 5: 41-66.

Miranda Escolar, Belén, and Ricardo Fernández Morueco. 2011. Vino, Turismo e Innovación: Las Rutas Del Vino de España, Una Estrategia Integrada de Desarrollo Rural. Estudios de Economía Aplicada 29: 129-65.

Mitchell, Richard, and C. Michael Hall. 2006. Wine Tourism Research: The State of Play. Tourism Review International 9: 307-32. [CrossRef]

Mitchell, Richard, Steve Charters, and Julia Nina Albrecht. 2012. Cultural Systems and the Wine Tourism Product. Annals of Tourism Research 39: 311-35. [CrossRef]

MTV. 2020. Movimento Del Turismo Del Vino. Available online: http://www.movimentoturismovino.it/it/home/ (accessed on 14 June 2020). 
Northwood, Gillian Mary. 2000. The Role of Wine Tourism in Economic Development: A Case Study of Niagara Region. ProQuest Dissertations and Theses. Master Thesis, Wilfrid Laurier University, Waterloo, ON, Canada. Available online: https://scholars. wlu.ca/etd/421/ (accessed on 2 February 2021).

O'Neill, Martin, Adrian Palmer, and Steven Charters. 2002. Wine Production as a Service Experience-The Effects of Service Quality on Wine Sales. Journal of Services Marketing. [CrossRef]

OIV. 2020. Organización Internacional de La Viña y El Vino. Available online: www.oiv.int (accessed on 7 July 2020).

Pepper, Coral, and Helen Wildy. 2009. Using Narratives as a Research Strategy. Qualitative Research Journal. [CrossRef]

Pérez-Calderón, Esteban, Francisco Javier Ortega-Rossell, and Patricia Milanés-Montero. 2015. The Wine Routes of Spain Products Club: The Case of the Ribera of Guadiana Wine Route (Spain). In Wine and Tourism: A Strategic Segment for Sustainable Economic Development. Cham: Springer. [CrossRef]

Peters, Gary L. 2018. American Winescapes: The Cultural Landscapes of America's Wine Country. New York: Routledge. [CrossRef]

Privitera, Donatella. 2010. Heritage and Wine as Tourist Attractions in Rural Areas. Paper presented at 116th EAAE Seminar, Parma, Italy, October 27-30.

Pulpón, Ángel Raúl Ruiz, and María Del Carmen Cañizares Ruiz. 2019. Potential of Vineyard Landscapes for Sustainable Tourism. Geosciences 9: 472. [CrossRef]

Quintal, Vanessa, Ben Thomas, Ian Phau, and Zorana Soldat. 2017. Using push-pull winescape attributes to model Australian wine tourist segmentation. International Journal of Wine Business Research 29. [CrossRef]

Ramis Hernández, A. 2010. Turismo y Vino En El Mundo: El Caso de Bodegas Enrique Mendoza. Universidad de Alicante. Available online: http:/ /hdl.handle.net/10045/15168 (accessed on 20 April 2020).

Riera Palmero, Juan. 2014. El Vino y La Cultura. Anales de la Real Academia de Medicina y Cirugía de Valladolid 51: 201-40.

Roman, Michał, Monika Roman, Piotr Prus, and Małgorzata Szczepanek. 2020. Tourism Competitiveness of Rural Areas: Evidence from a Region in Poland. Agriculture 10: 569. [CrossRef]

Ruiz-Romero de la Cruz, Elena, Elena Cruz-Ruiz, and Gorka Zamarreño-Aramendia. 2017. Rutas Enológicas y Desarrollo Local. Presente y Futuro en La Provincia de Málaga. International Journal of Scientific Management and Tourism 3: $283-310$.

Ruiz-Romero de la Cruz, Elena, Gorka Zamarreño-Aramendia, and Elena Cruz-Ruiz. 2019. The Sustainability of the Territory and Tourism Diversification. A Comparative Analysis of the Profile of the Traditional and the Oenologic Tourist through the Future Route of Wine in Malaga. Journal of Business and Economics 10. [CrossRef]

Saybus. 2020. L'œnotourisme En France. Available online: https://saybus.fr/publications/loenotourisme-en-france/\#: \{\}:

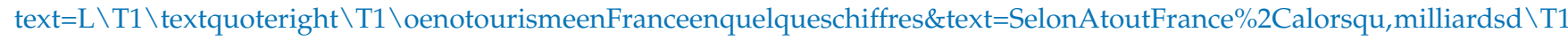
$\backslash$ textquoterighteurosen2016. (accessed on 10 January 2021).

Sigala, Marianna. 2014. Wine Tourism around the World: Development, Management and Markets. Journal of Wine Research. [CrossRef] Sparks, Beverley. 2007. Planning a Wine Tourism Vacation? Factors That Help to Predict Tourist Behavioural Intentions. Tourism Management 25: 1180-92. [CrossRef]

Triantafyllou, Georgios, Strataki Eirini, and George Apladas. 2020. Positioning an emerging wine route in the Island of Crete: Interpreting the wine tourism market and its implications for marketing. Journal of Tourism Quarterly 2: 79-93.

Trišić, Igor, Snežana Štetić, Donatella Privitera, and Adrian Nedelcu. 2020. Wine Routes in Vojvodina Province, Northern Serbia: A Tool for Sustainable Tourism Development. Sustainability 12: 82. [CrossRef]

Vasco Santos, Ribeiro, Paulo Ramos, Nuno Almeida, and Enrique Santos-Pavón. 2019. Wine and wine tourism experience: A theoretical and conceptual review. Worldwide Hospitality and Tourism Themes 11. [CrossRef]

Vázquez Palmero, Francisca, Genoveva Millán Vazquez de la Torre, and Juan Arjona Fuentes. 2017. Enoturismo en un destino de sol y playa. el caso de málaga, una revisión bibliográfica. International Journal of Scientific Management and Tourism 3: 591-608.

Vieira-Rodríguez, Áurea, Tomás López-Guzmán, and Juan Rodríguez García. 2013. Analysis of the Wine Tourist in the Designation of Origin for Sherry (Spain). Tourism \& Management Studies 9: 37-43. [CrossRef]

Wade, Richard I, Christopher Pinto, Hersch Jacobs, and David Martin. 2006. Wine Tourism: Motivations of Winery Visitation in the Niagara Wine Region. Paper presented at 24th EuroCHRIE Conference, Thessaloniki, Greece, July 21.

Wargenau, Astrid, and Deborah Che. 2006. Wine Tourism Development and Marketing Strategies in Southwest Michigan. International Journal of Wine Marketing. [CrossRef]

Wilkins, Matthew, and C. Michael Hall. 2001. An Industry Stakeholder SWOT Analysis of Wine Tourism in the Okanagan Valley, British Columbia. International Journal of Wine Marketing. [CrossRef]

Williams, Peter W., and Joseph Kelly. 2001. Cultural Wine Tourists: Product Development Considerations for British Columbia's Resident Wine Tourism Market. International Journal of Wine Marketing 13: 59-76. [CrossRef]

Wolikow, Serge. 2014. Le Vin de Champagne: De La Visite à l'Oenotourisme, Un Chemin Difficile. CULTUR: Revista de Cultura e Turismo 8: 172-87.

Yagüe Guillén, María, and Ana Jiménez. 2002. La Denominación de Origen En El Desarrollo de Estrategias de Diferenciación: Percepción y Efectos de Su Utilización En Las Sociedades Vinícolas de Mancha y Valdepeñas. Revista Española de Estudios Agrosociales y Pesqueros, 179-204. [CrossRef] 